\title{
Investigation of technogenic deposits of phosphogypsum dumps
}

\author{
Viktor Moshynskyi ${ }^{1}$, Ruslan Zhomyruk ${ }^{2}$, Oleksandr Vasylchuk ${ }^{3 *}$, Vasil Semeniuk ${ }^{3}$, Roman $_{\text {Okseniuk }}{ }^{3}$, Kanay Rysbekov $^{4}$, \\ and Kassym Yelemessov 5 \\ ${ }^{1}$ National University of Water Management and Nature Resources Use, Department of Land Management, Cadastre, Monitoring of the \\ Earth and Geoinformatics, 11 Soborna Str., Rivne, 33028, Ukraine \\ ${ }^{2}$ National University of Water Management and Nature Resources Use, Department of Automation, Electrical Engineering and \\ Computer-Integrated Technologies, 11 Soborna Str., Rivne, 33028, Ukraine \\ ${ }^{3}$ National University of Water Management and Nature Resources Use, Department of Development of Deposits and Mining, 11 Soborna \\ Str., Rivne, 33028, Ukraine \\ ${ }^{4}$ Satbayev University, Institute of Geology, Petroleum and Mining engineering, 22a Satpaev Str., Almaty, 050013, Kazakhstan \\ ${ }^{5}$ Satbayev University, Institute of Metallurgy and Industrial Engineering, 22a Satpaev Str., Almaty, 050013, Kazakhstan
}

\begin{abstract}
The article contains research materials on the storage of man-made deposits, including phosphogypsum dumps. The consequences of long-term operation of phosphogypsum dumps and their negative impact on the environment have been established. The quantitative content of microelements to the soil within the storage of technogenic phosphogypsum deposit was determined. Graphical dependences of phosphorus, manganese, fluorine, mobile sulfur, zinc, nickel content depending on the depth of sampling and distance from phosphogypsum dumps to settlements and the Goryn River are presented. The directions of processing and utilization of the given waste are offered. The elemental composition of phosphogypsum dumps of PJSC "Rivneazot" has been established, in particular, the presence of a group of valuable rare earth elements.
\end{abstract}

\section{Introduction}

Mining is the basis of the economy of any country [1, 2]. Since minerals are exhaustible, there is a need to process existing raw materials, including processed products of other industries $[3,4]$.

The problem of reduction and utilization of waste from various industries is very acute at the present stage of existence of the population around the world $[5,6]$.

According to the Rivne Geological Exploration Expedition, about 1,200 stationary landfills for soil and groundwater pollution have been identified in the Rivne region. Among the latter, a man-made phosphogypsum deposit poses a significant threat to human life and health, as well as a negative impact on environmental systems. It was formed as an inevitable multi-ton waste as a result of many years of production of phosphoric acid at PJSC "Rivneazot" [7].

Man-made deposit from phosphogypsum dumps of PJSC "Rivneazot", located in Rivne district at a distance of $1.5 \mathrm{~km}$ northeast of the village of Metkiv, and at a distance of $1 \mathrm{~km}$ east of the village of Rubche (Fig. 1) [8].

There are a significant number of such man-made phosphogypsum deposits in Ukraine and around the world. Most of them are not used, but only constantly accumulated [9].

Significant areas of agricultural land are allocated for phosphogypsum storage $[10,11]$. Thus, phosphogypsum dumps of PJSC "Rivneazot" cover an area of 58 hectares and their total volume is 15.2 million tons [7].

It is known that when stored outdoors, under the influence of atmospheric factors, acid residues and large amounts of impurities, phosphogypsum enters groundwater and affects the ecosystem. Among these impurities are found rare earth elements (REE), the extraction of which does not occur $[7,12,13]$.

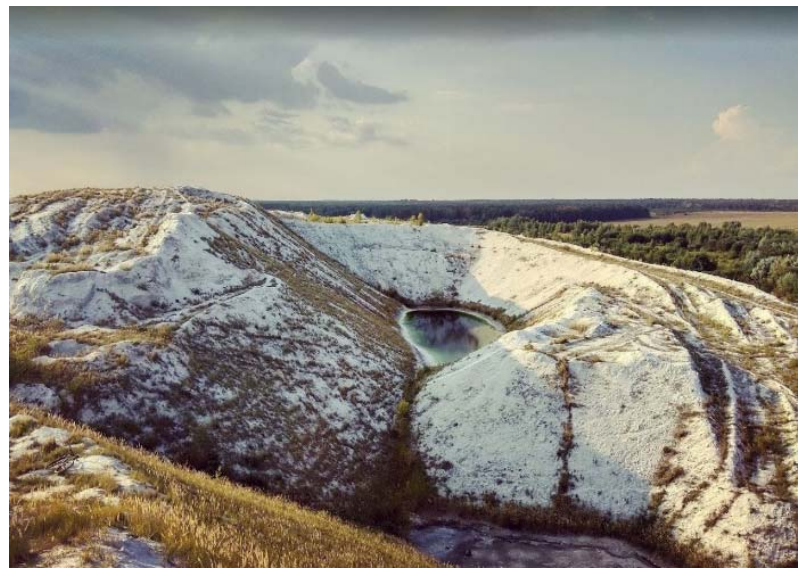

Fig. 1. Man-made phosphogypsum deposit of PJSC "Rivneazot" (photo taken from open sources).

Rare earth elements are widely used in the production of high-tech products. REE includes chemical elements:

\footnotetext{
* Corresponding author: o.y.vasylchuk@nuwm.edu.ua
} 
Sc, Y, La and 14 elements of the lanthanide family. The total demand for these materials in 2013 amounted to 136 thousand tons [14] and now it is about 200.000 tons, which indicates an increase in demand by $47 \%$ [15]. New energy-saving fluorescent lamps, which include: yttrium, lanthanum, cerium, europium, gadolinium, terbium, have become widespread. Due to their low toxicity, REE are used in the manufacture of rechargeable La-Ni-H batteries, which will eventually be able to displace leadacid batteries in automobiles and nickel-cadmium batteries in computers. Elements of the lanthanide family are used in the glass industry to create optical glass in the charge is injected lanthanum oxide (from 5\% to $40 \%$ ) which increases heat resistance and acid resistance, such glass is used for the production of lenses and prisms of telescopes, cameras, film cameras and laboratory glass [16]. Lanthanum nickel hydride is widely used as the basis for high-capacity batteries for hybrid cars, and the cerium dioxide catalyst is widely used in the petrochemical industry.

Therefore, it is already possible to consider man-made deposits of phosphogypsum as a raw material for the extraction of valuable rare earth elements. According to research, phosphogypsum waste contains up to $1 \%$ REE.

The use, processing and utilization of phosphogypsum waste is an urgent scientific and applied problem, the solution of which will improve the ecological situation in the storage areas of man-made phosphogypsum deposits and bring significant economic effect for the national economy $[17,18]$.

\section{Materials and methods}

The object of the study is the phosphogypsum dumps of PJSC "Rivneazot" and the adjacent territory (Fig. 2). This is a waste of the fourth class of danger, which is represented mainly by phosphorus oxides that accumulate in the dumps of phosphogypsum [7].

Phosphogypsum refers to calcium sulfate dihydrate. It mainly consists of gypsum $\left(\mathrm{CaSO}_{4} \cdot 2 \mathrm{H}_{2} \mathrm{O}\right)$, impurities $\mathrm{P}_{2} \mathrm{O}_{5}$ (undecomposed phosphate, unwashed phosphoric acid, crystallized $\mathrm{P}_{2} \mathrm{O}_{5}$ and water) and other inclusions of trace elements, including REE [19, 20].

Phosphogypsum is a polydisperse material that has a grayish-white color. It is represented by aggregates of particles, lumps with interunit cavities. The density of phosphogypsum is $2.2 \ldots 2.4 \mathrm{~g} / \mathrm{cm}^{3}$, relative humidity $25 \ldots 30 \%$, bulk density $0.67 \ldots 0.93 \mathrm{~g} / \mathrm{cm}^{3}$, porosity $71.5 \ldots 76.3[21,22]$.

Hunting canals have been designed to intercept surface runoff and prevent contamination of soils and groundwater around the perimeter of the facility, and a pumping station has been designed to pump water from the site. Water is diverted to the treatment facilities of PJSC "Rivneazot". Currently, the pumping station is out of order. The water in the canals is highly mineralized, as evidenced by the results of research and dry trees in the riverbed, the water pressure in the canals is $0.5 \mathrm{~m}$. To the object from the side of the village Metkiv there is a concrete road that connects PJSC "Rivneazot" and manmade dumps of phosphogypsum [7].

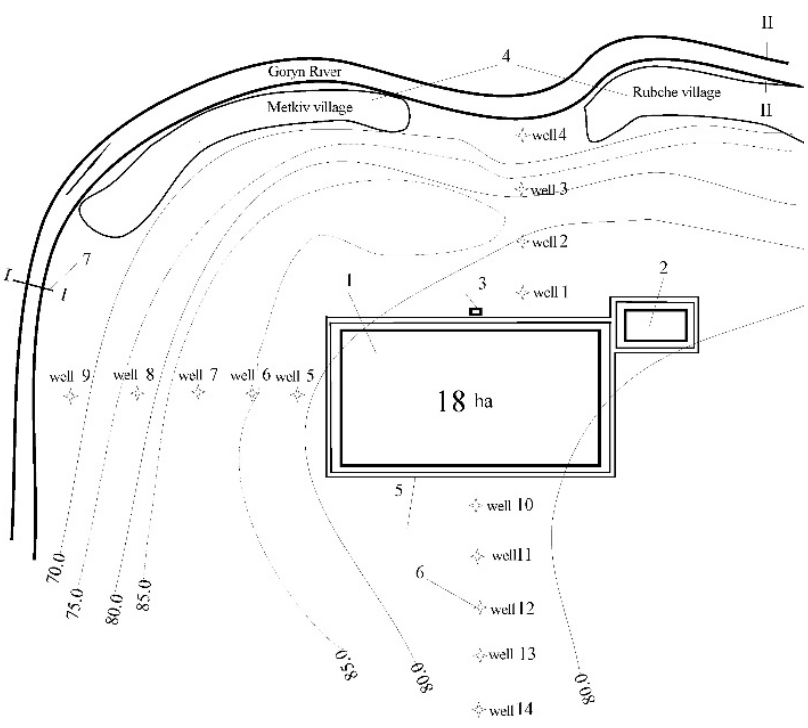

Fig. 2. Experimental area - phosphogypsum dumps of OJSC "Rivneazot": 1 - phosphogypsum dumps; 2 - storage of solid toxic substances; 3 - pumping station; 4 - settlements; 5 - system of channels for interception of surface runoff; 6 - wells for soil sampling; 7 - places of water sampling from the river Goryn, 8 - treatment facilities;w. 1 - w.14 - wells for soil sampling; I, II - create for water sampling in the river Goryn.

To determine the content of contamination in soils and in the Goryn River, the study was conducted in two stages: at the first stage, soil and water samples were taken at the Goryn River, and at the second stage, the study results were processed.

To take soil samples, the experimental plot was divided into three sights, which were projected on the lowest points of the terrain. The first line west of the warehouse in the direction of the village. Rubche $1 \mathrm{~km}$ long; the second to the south of the object is $1.5 \mathrm{~km}$ long; the third to the east of the object towards the forest, 0.9 $\mathrm{km}$ long. The total number of wells is 14 pcs.

In Fig. 3 shows a longitudinal section of the target №1.

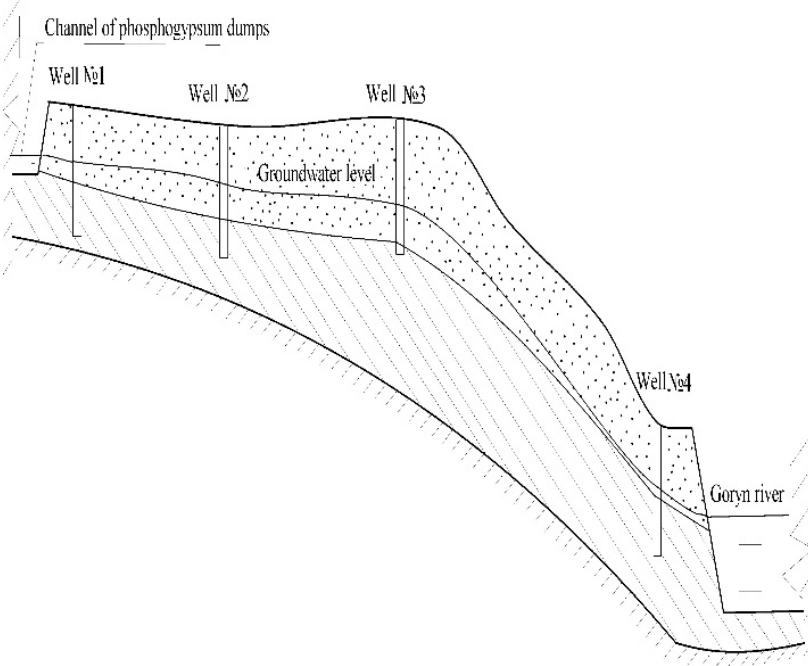

Fig. 3. Scheme of longitudinal section on the target №1: 1 - sand; 2 - loam; 3 - water resistance.

Wells for sampling were drilled by hand drill (geological drill, diameter $50 \mathrm{~mm}$ ) to a depth of $6 \mathrm{~m}$. Soil 
samples were taken every meter, starting from the surface with three repetitions of each sample. The distances between the wells in the first three lines are 50, 250, 300, $400 \mathrm{~m}$, respectively. Along the first line there is a decrease of the territory towards the river Goryn. The distances between the wells in the second line, respectively, 50, 250, 300, 400, $500 \mathrm{~m}$

Processing of data of field measurements was carried out jointly with specialists in the laboratory of the State Department of Ecology and Natural Resources in Rivne region [23, 24].

The raw material for the extraction of rare earth elements was phosphogypsum from the dumps of PJSC "Rivneazot" [7, 8, 25]. Sampling points on the territory of the dump were determined for research (Fig. 4).

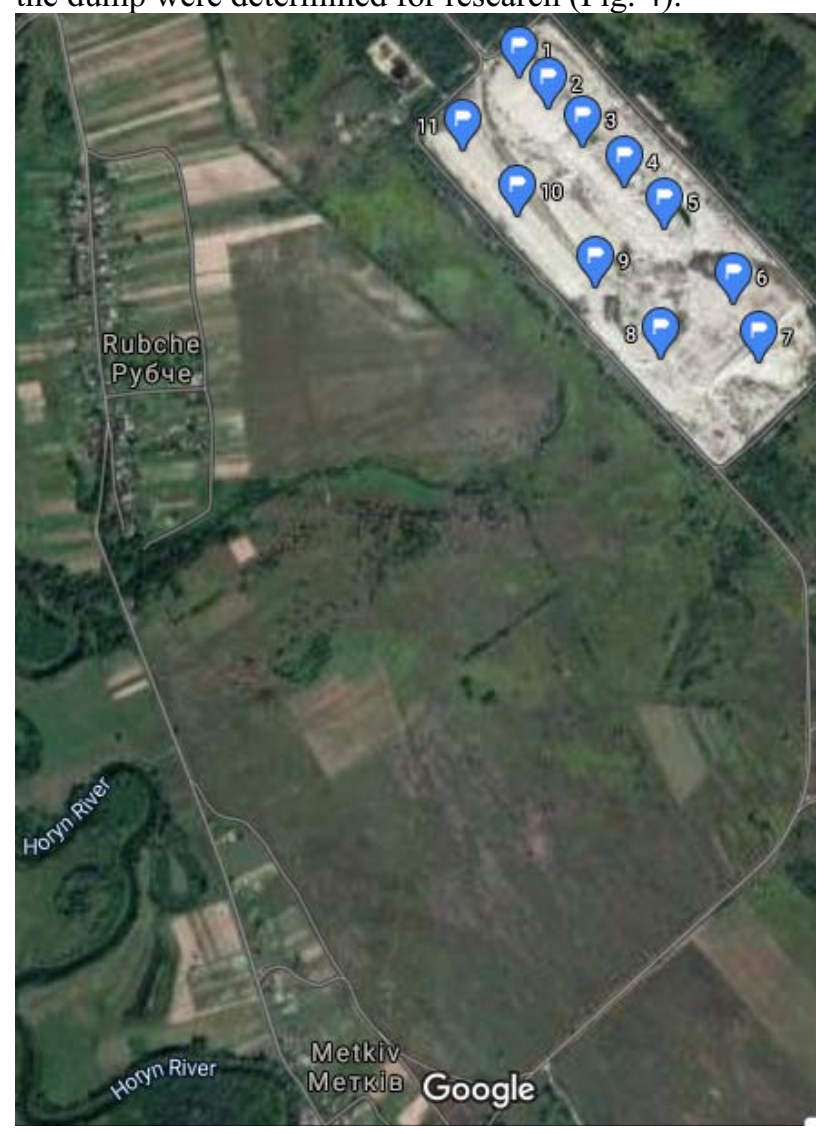

Fig. 4. Location of technogenic deposit and place of phosphogypsum sampling on dumps of PJSC "Rivneazot".

Graphical coordinates of the points were determined using a Garmin GPSMAP 64 navigator: sample 1 $\left(50^{\circ} 44^{\prime} 47.9^{\prime \prime} \mathrm{N} 26^{\circ} 10^{\prime} 53.5^{\prime \prime} \mathrm{E}\right)$, sample $2\left(50^{\circ} 44^{\prime} 45.8^{\prime \prime} \mathrm{N}\right.$ $\left.26^{\circ} 10^{\prime} 56.4^{\prime \prime} \mathrm{E}\right)$, sample $3\left(50^{\circ} 44^{\prime} 43.4^{\prime \prime} \mathrm{N} 26^{\circ} 10^{\prime} 60.0^{\prime \prime} \mathrm{E}\right)$, sample $4 \quad\left(50^{\circ} 44^{\prime} 40.8^{\prime \prime} \mathrm{N} \quad 26^{\circ} 11^{\prime} 04.1 " \mathrm{E}\right)$, sample 5 $\left(50^{\circ} 44^{\prime} 38.2^{\prime \prime} \mathrm{N} 26^{\circ} 11^{\prime} 08.2^{\prime \prime} \mathrm{E}\right)$, sample $6\left(50^{\circ} 44^{\prime} 33.4^{\prime \prime} \mathrm{N}\right.$ $\left.26^{\circ} 11^{\prime} 15.3^{\prime \prime} \mathrm{E}\right)$, sample 7 (50॰44'29.6"N 26¹1'17.8"E), sample $8 \quad\left(50^{\circ} 44^{\prime} 29.9^{\prime \prime} \mathrm{N} \quad 26^{\circ} 11^{\prime} 07.9^{\prime \prime} \mathrm{E}\right)$, sample 9 $\left(50^{\circ} 44^{\prime} 34.4^{\prime \prime} \mathrm{N} 26^{\circ} 11^{\prime} 01.2^{\prime \prime} \mathrm{E}\right)$, sample $10\left(50^{\circ} 44^{\prime} 39.0^{\prime \prime} \mathrm{N}\right.$ $\left.26^{\circ} 10^{\prime} 53.3^{\prime \prime} \mathrm{E}\right)$, sample 11 (50॰44'43.1"N 26¹0'47.9"E). A total of 11 samples were taken, with a total of $25 \mathrm{~kg}$.

Before the research, a quantitative chemical analysis was performed to determine the elemental composition of raw materials $[26,27]$.

\section{Results and discussion}

\subsection{Research of phosphogypsum storage landfill}

As a result of chemical analysis of water and soil samples taken on the territory of the experimental site, the content of microelements in the experimental samples was determined. The content of nitrates $\mathrm{NO}_{3}$, fluorine $\mathrm{F}$, mobile phosphorus $\mathrm{P}_{2} \mathrm{O}_{5}$, mobile sulfur $\mathrm{S}$, zinc, iron, cobalt, nickel, lead, manganese, copper and chromium in soil samples in $\mathrm{mg} / \mathrm{kg}$ was determined. The $\mathrm{pH}$ of the water extract was determined. Graphical dependences of the content of microelements in the soil on the length of the target for each depth of sampling are constructed.

The results are presented for the target №1. It is directed towards the village Rubche and Horyn river, therefore, the obtained data are of the greatest value in terms of impact on soil and groundwater pollution due to the storage of man-made phosphogypsum deposits.

In fig. 5. and fig. 6. graphical dependences of phosphorus and manganese content on the length of the line, respectively, are presented. Samples were taken at a depth of 1 to $6 \mathrm{~m}$.

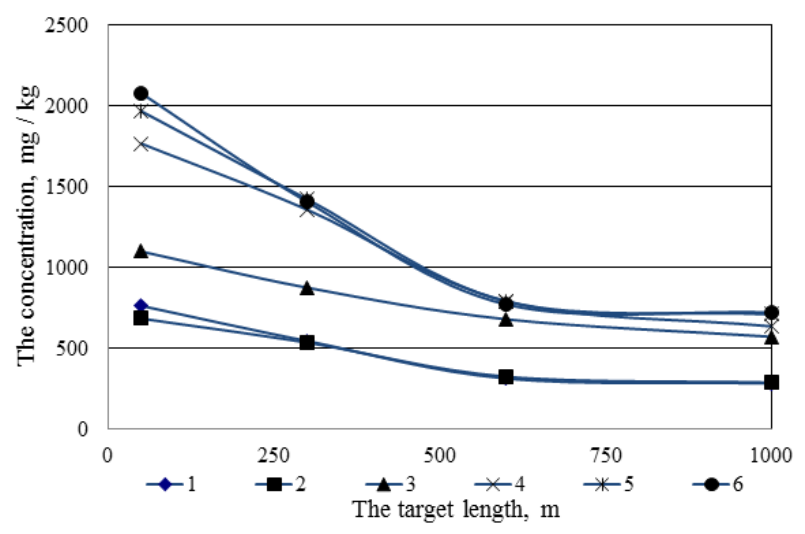

Fig. 5. Dependence of phosphorus content on the length of the target: $1-\mathrm{h}=1 \mathrm{~m} ; 2-\mathrm{h}=2 \mathrm{~m} ; 3-\mathrm{h}=3 \mathrm{~m} ; 4-\mathrm{h}=4 \mathrm{~m} ; 5-\mathrm{h}=5 \mathrm{~m}$; $6-\mathrm{h}=6 \mathrm{~m}$.

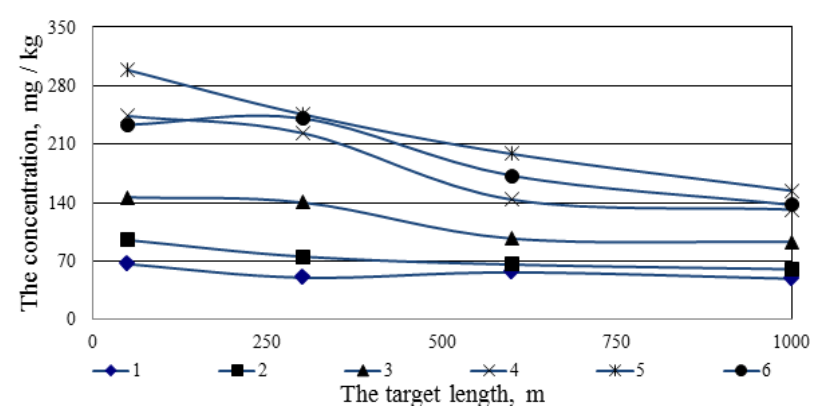

Fig. 6. Dependence of manganese content on the length of the target: $1-\mathrm{h}=1 \mathrm{~m} ; 2-\mathrm{h}=2 \mathrm{~m} ; 3-\mathrm{h}=3 \mathrm{~m} ; 4-\mathrm{h}=4 \mathrm{~m} ; 5-\mathrm{h}=5$ $\mathrm{m} ; 6-\mathrm{h}=6 \mathrm{~m}$.

As a result of the analysis of the presented graphic dependences it is established that the concentration of phosphorus varies in the range from 286 to $2078 \mathrm{mg} / \mathrm{kg}$. It is also seen that the concentration of phosphorus in the soil decreases depending on the distance from the phosphogypsum dump, and increases with increasing depth. 
The nature of the dependences of the manganese content in the soil is similar to the dependences for phosphorus. Numerical characteristics vary from 48.9 to $298.7 \mathrm{mg} / \mathrm{kg}$.

Studies of the content of microelements from the length of the target at a depth of up to $6 \mathrm{~m}$ were also carried out. In Fig. 7 the results are presented at a depth of $3 \mathrm{~m}$, and in Fig. $8-5 \mathrm{~m}$.

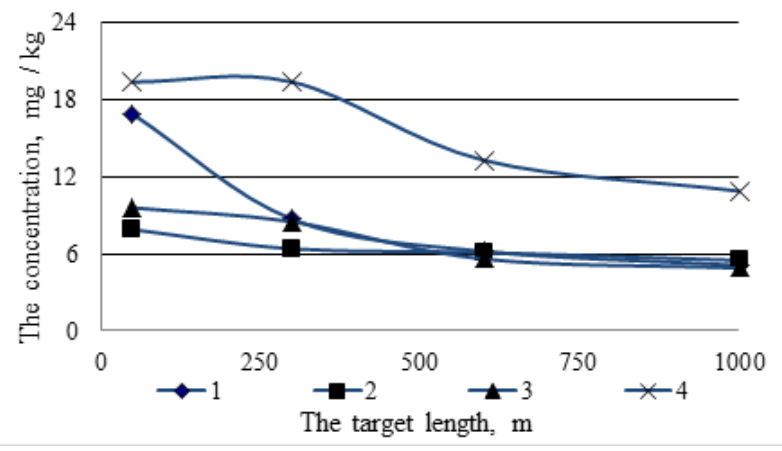

Fig. 7. Dependence of the content of microelements on the length of the target at a depth of $3 \mathrm{~m}$ from the soil surface, mg/kg: 1 - fluorine; 2 - mobile sulfur; 3 - zinc; 4 - nickel.

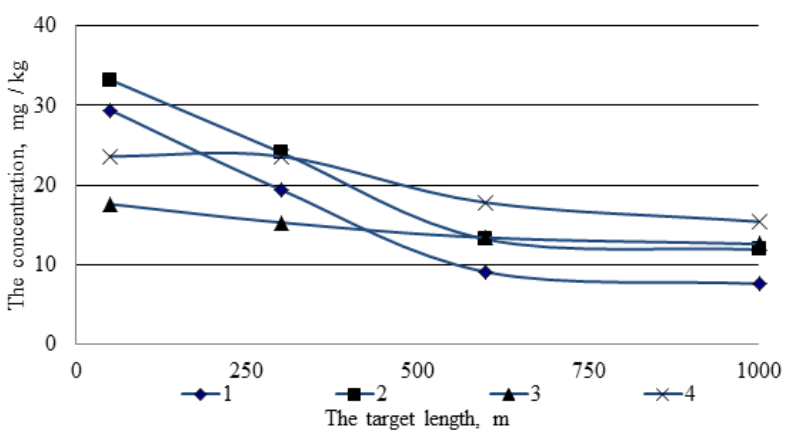

Fig. 8. Dependence of the content of microelements on the length of the target at a depth of $5 \mathrm{~m}$ from the soil surface, mg/kg: 1 - fluorine; 2 - mobile sulfur; 3 - zinc; 4 - nickel.

The result of the obtained data showed that the content of such microelements as fluorine, mobile sulfur, zinc and nickel increases with depth, and decreases with distance from the man-made phosphogypsum deposit.

When comparing the data obtained experimentally and the data of the State Department of Ecology and Natural Resources in Rivne region, there is a tendency of significant accumulation in time of harmful chemical elements in the soil. The content of lead, zinc, copper, cadmium, nickel, cobalt, nitrites, manganese, phosphorus exceeds the maximum allowable norms. Thus, in samples taken at a distance of $500 \mathrm{~m}$ to the west in 2000 , the content of mobile phosphorus in the soil is $332 \mathrm{mg} / \mathrm{kg}$, and in $2019-670 \mathrm{mg} / \mathrm{kg}$. As a result, it can be concluded that it is necessary to reconstruct the system of protection of soils and groundwater from pollution by harmful substances on the territory of phosphogypsum dumps near the production site of PJSC "Rivneazot", or the introduction of new more effective methods, which will ensure high-quality interception of pollutants at the outlet of the facility and will not cause an environmentally unfavorable state of the environment. Another way to reduce the negative impact on environmental systems is to develop a project for integrated disposal of phosphogypsum dumps.

\subsection{Investigation of man-caused phosphogypsum deposit}

From the raw materials obtained for research from phosphogypsum dumps, a quantitative chemical analysis was performed, the results of which are presented in Table 1. For comparison, the results of quantitative chemical analysis of phosphogypsum OJSC "PhosAgroCherepovets" (Russia) are presented [28].

Table 1. Quantitative analysis of raw materials from phosphogypsum dumps.

\begin{tabular}{|c|c|c|}
\hline Element & $\begin{array}{c}\text { Phosphogypsum of } \\
\text { OJSC "PhosAgro- } \\
\text { Cherepovets", wt.\% }\end{array}$ & $\begin{array}{c}\text { Phosphogypsum } \\
\text { PJSC "Rivneazot", } \\
\text { wt.\% }\end{array}$ \\
\hline Sulfates & 54.4 & 52.5 \\
\hline $\begin{array}{c}\text { Aluminum } \\
\text { oxide }\end{array}$ & 0.2 & 0.15 \\
\hline Boron oxide & 0.0092 & 0.01 \\
\hline Cadmium & 0.00032 & 0.003 \\
\hline Cobalt & - & 0.0012 \\
\hline Chrome & 0.002 & 0.018 \\
\hline Copper & 0.0014 & 0.0018 \\
\hline Iron oxide & 0.025 & 0.034 \\
\hline $\begin{array}{c}\text { Potassium } \\
\text { oxide }\end{array}$ & 0.055 & 0.064 \\
\hline $\begin{array}{c}\text { Magnesium } \\
\text { oxide }\end{array}$ & 0.17 & 0.187 th most \\
\hline common
\end{tabular}

In fig. 9 the content of REE oxides of light group of technogenic phosphogypsum deposit of PJSC "Rivneazot" is presented. 


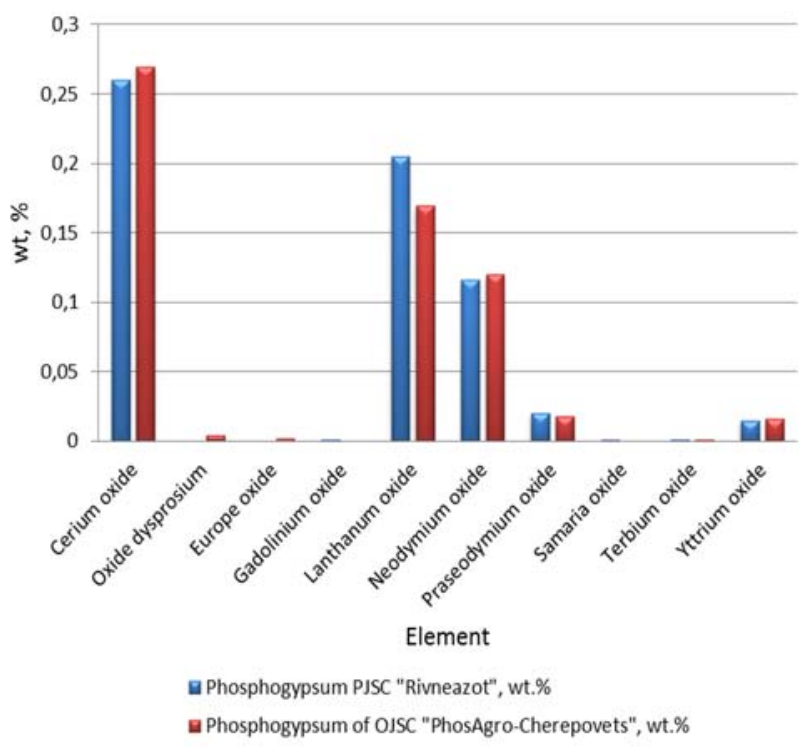

Fig. 9. Oxides of rare earth elements of the light group.

As can be seen from Table 1 and Fig. 9 in the dumps of phosphogypsum PJSC "Rivneazot" presents 8 rare earth elements. The main mass fraction is REE oxides of the light group. These include four elements: lanthanum, cerium, neodymium, praseodymium, the different content of which in concentrates of enrichment determines their commercial value.

\subsection{Areas of use of phosphogypsum}

The main areas of use of phosphogypsum in the national economy include [29, 30]:

- agriculture, as fertilizers and for reclamation of acid soils;

- use as pavements;

- as creation of X-ray protective designs;

- use as mineralizing additives in the firing of cement clinker;

- in the construction industry, for the production of building materials, production of gypsum binders and production of hydraulic additives;

- as a filler: in the production of paper instead of kaolin, in the paint and varnish industry and in the production of plastics, glass, ammonium nitrate instead of traditional materials (heat-treated phosphogypsum instead of sodium sulfate, etc.);

- mines of coal and other industries - to fill the fastening space and calculation of security strips;

- extraction of rare earth elements.

\section{Conclusions}

Solving the problem of processing or utilization of waste that forms man-made deposits of phosphogypsum is an important application, the solution of which will significantly improve the ecological state of the environment.

The research was carried out on the example of a manmade phosphogypsum deposit of PJSC "Rivneazot", located in Rivne region.
According to research, the parameters of micronutrient distribution in the soil around phosphogypsum dumps have been established. The content of lead, zinc, copper, cadmium, nickel, cobalt, nitrites, manganese, phosphorus exceeds the maximum allowable norms. The concentration of these trace elements in the soil decreases with distance from the dumps.

The main areas of use of phosphogypsum in the national economy are agriculture, the manufacture of $\mathrm{X}$ ray protective structures, the extraction of rare earth elements.

According to the results of quantitative chemical analysis, it was found that phosphogypsum dumps contain $0.629 \%$ of REE oxides.

\section{References}

1. Malanchuk, Z., Korniienko, V., Malanchuk, E., Khrystiuk, A.: Results of experimental studies of amber extraction by hydromechanical method in Ukraine. Vostochno-Evropeyskiy zhurnal peredovykh tekhnologiy [Eastern-European Journal of Enterprise Technologies], 3, 10(81), 24-28 (2016). doi:10.15587/1729-4061.2016.72404

2. Naduty, V., Malanchuk, Z., Malanchuk, E., Korniyenko, V.: Modeling of vibro screening at fine classification of metallic basalt. Theoretical and Practical Solutions of Mineral Resources Mining, 441-443 (2015). doi: 10.1201/b19901-77

3. Malanchuk, Ye., Korniienko, V., Malanchuk, L., Zaiets, V.: Research into the moisture influence on the physical-chemical tuff-stone characteristics in basalt quarries of the Rivne-Volyn region. E3S Web of Conferences. $211 \quad$ (2020) doi:10.1051/e3sconf/202020101036

4. Korniyenko, V., Nadutyi, V., Malanchuk Y., Yeluzakh, M.: Substantiating velocity of amber buoying to the surface of sludge-like rock mass. Mining of Mineral Deposits. 14(4), 90-96 (2020). doi:10.33271/mining14.04.090

5. Malanchuk, Z., Moshynskyi, V., Malanchuk, Y.., Korniienko, V, Koziar, M.: Results of Research into the Content of Rare Earth Materials in Man-Made Phosphogypsum Deposits. Key Engineering Materials, (844), 77-87 (2020). doi:10.4028/www.scientist.net/KEM.844.77

6. Naduty, V, Malanchuk, Z., Malanchuk, E., Korniienko, V.: Research results proving the dependence of the copper concentrate amount recovered from basalt raw material on the electric separator field intensity. Eastern-European Journal of Enterprise Technologies, 5, 5(83), 19-24, (2016). doi:10.15587/1729-4061.2016.79524

7. Moshynskyi, V., Malanchuk, Z., Tsymbaliuk, V., Malanchuk, L., Zhomyruk, R., \& Vasylchuk, O.: Research into the process of storage and recycling technogenic phosphogypsum placers. Mining of Mineral Deposits, 14(2), 95-102 (2020). doi:10.33271/mining 14.02.095 
8. Malanchuk, Z., Korniienko, V., Malanchuk, Ye., Soroka, V., Vasylchuk, O.: Modeling the formation of high metal concentration zones in man-made deposits. Mining of Mineral Deposits, 12(2), 76-84, (2018). doi:10.15407/mining12.02.076

9. Abisheva, Z.S., Bochevskaya, E.G., Zagorodnyaya, A.N., Shabanova, T.A., Karshigina, Z.B.: Technology of phosphorus slag processing for preparation of precipitated silica. Theoretical Foundations of Chemical Engineering, 47(4), 428434. (2013). doi:10.1134/s0040579513040027

10. Abisheva, Z.S., Karshigina, Z.B., Bochevskaya, Y.G., Akcil, A., Sargelova, E.A., Kvyatkovskaya, M.N., \& Silachyov, I.Y.: Recovery of rare earth metals as critical raw materials from phosphorus slag of long-term storage. Hydrometallurgy, (173), 271282 (2017). doi:10.1016/j.hydromet.2017.08.022

11. Naimanbayev, M.A., Lokhova, N.G., Baltabekova, Zh.A., Dukembayeva A.Zh.: Thermodynamic assessment of conversion of phosphogypsum components in carbonates. Integrated use of mineral resources, 5. 55-59 (2011)

12. Lushnikova, N., \& Dvorkin, L.: Sustainability of gypsum products as a construction material. Sustainability of Construction Materials, 643-681 (2016). doi:10.1016/b978-0-08-100370-1.00025-1

13. Cánovas, C.R., Macías, F., Pérez López, R., \& Nieto, J.M.: Mobility of rare earth elements, yttrium and scandium from a phosphogypsum stack: Environmental and economic implications. Science of the Total Environment, 618, 847-857 (2018). doi:https://doi.org/10.1016/j.scitotenv.2017.08.220

14. Humphries, M.: Rareear the lements: the global supply chain. Congressional Research Service Report, R41347 (2013)

15. Mishra, B., Anderson, A.: Extraction and recovery of rare-earthmetals: challenge sinproces sing. ERES 2014, 1st European Rare Earth Resources Conference, 19-25 (2014)

16. Binnemans, K., Tom Jones, P., Blanpain, B., Van Gerven, T., Pontikes, Y.: Towards zero-waste valorisation of rare-earth-containing industrial process residues: a critical review. J. Clean. Prod. 99, 17e38 (2018)

17. Yanxia, L., Lei, Y., Yajun, C., Saud, S., Jingjing, L., Hui, Y., \& Liyuan Zhao.: Landscape Transformation in Mining Wastelands. Journal of Northeast Agricultural University (English Edition), 23(1), 8388 (2016). doi:10.1016/s1006-8104(16)30036-8

18. Nadutyi, V., Korniyenko, V., Malanchuk, Z., Cholyshkina, O.: Analytical presentation of the separation of dense suspension for the extraction of amber. E3S Web of Conferences, International Conference Essays of Mining Science and Practice, 109 , 00059

(2019). doi:10.1051/e3sconf/201910900059

19. Jha, M.K., Kumari, A., Panda, R., Rajesh Kumar, J., Yoo, K., \& Lee, J.Y.: Review on hydrometallurgical recovery of rare earth metals. Hydrometallurgy,
(161), 77-101 (2016). doi:https://doi.org/10.1016/j.hydromet.2016.01.003

20. Dutrizac, J.E.: The behaviour of the rare earth elements during gypsum precipitation. Hydrometallurgy 174, 38e46 (2017)

21. Wang, X., Lei, Y., Ge, J., Wu, S.: Production for ecas of China's rare earth based on the Generalized Weng model and policy recommendations, Resour. Policy 43, 11-18 (2015)

22. Wang, S., Zhang, H., Zou, Z., Wang, P., \& Yu, T.: Potential Risk Analysis of Tailings Dam under Preloading Condition and Its Countermeasures. Journal of Engineering and Technological Sciences, 47(1), 46-56 (2015). doi:https://doi.org/10.5614/j.eng.technol.sci.2015.47 .1 .4

23. Malanchuk, Z., Malanchuk, Y., Khrystiuk, A.: Mathematical modeling of hydraulic mining from placer deposits of minerals. Mining Of Mineral Deposits, 10(2), 18-24 (2016). doi: 10.15407/mining 10.02.013

24. Malanchuk, Y., Malanchuk, Z., Korniienko, V., Gromachenko, S. The results of magnetic separation use in ore processing of metalliferous raw basalt of Volyn region. Mining Of Mineral Deposits, 10(3), 77- 83 (2016). doi: 10.15407/mining10.03.077

25. Bomba, A., Tkachuk, M., Havryliuk, V., Kyrysha, R., Gerasimov, I., Pinchuk, O.: Mathematical modelling of filtration processes in drainage systems using conformal mapping. Journal of Water and Land Development, 39(1), 11-15 (2018). doi:https://doi.org/10.2478/jwld-2018-0054

26. Malanchuk, Z., Korniienko, V., Malanchuk, Y. Results of research into amber mining by hydromechanical method. Mining Of Mineral Deposits, 11 (1), 93-99 (2017). doi: 10.15407/mining11.01.093

27. Sokolov, V.A., \& Udalov, I.V.: Mineral and raw material base of agronomical ore in Kharkiv region. Visnyk of V.N. Karazin Kharkiv National University - Series Geology, Geography, Ecology, (47), 206210 (2017). doi:https://doi.org/10.26565/2410-73602017-47-27

28. Artamonov, A.V., Smirnova, D.N., Smirnov, N.N., Ilyin, A.P.: Extraction of rare earth elements from solid wastes of phosphoric acid production with subsequent sorption on cation-exchange resins. Izv. Vyssh. Uchebn. Zaved. Khim. Khim. Tekhnol, 60 (10), 87-93 (2017). doi:10.6060/tcct.20176010.5571

29. Canovas, C.R., Perez-Lopez, R., Macías, F., Chapron, S., Nieto, J.M., Pellet-Rostaing, S.: Exploration of fertilizer industry wastes as potential source of critical raw materials. J. Clean. Prod. 143, 497e505 (2017)

30. Lokshin, E.P., Tareeva, O.A.: Production of highquality gypsum raw materials from phosphogypsum. Russ. J. Appl. Chem. 88, 567e573 (2015). 